\title{
TOCOPHEROLS: THEIR ROLE IN STABILIZING ANHYDROUS BUTTER-FAT (Ghee) AND BUTTER COOKIES
}

\author{
Shaltout, Omayma, E. ${ }^{1}$, El-Sini, Madeha, N. $^{2}$ \& El-Khateib, Mona, H. ${ }^{3}$ \\ ${ }^{1}$ Food Science Dept., Fac. of Agric. (Saba Basha), Alex. Univ., Alexandria, Egypt. \\ ${ }^{2}$ Biochemistry Dept., Fac. of Sci., King Abdulaziz Univ., Jeddah, KSA. \\ ${ }^{3}$ Food \& Nutrition Dept., Home Economics, King Abdulaziz Univ., Jeddah, KSA.
}

\begin{abstract}
Two different concentrations of mixed Tocopherols known commercially as Covi-OxT50 (Covi 50) and Covi-OxT70 (Covi 70) together with a single concentration of a synthetic antioxidant known as Tenox 25 (T25) were added to butter and anhydrous butter fat (ABF) Ghee. Butter cookies made from the aforementioned butter were prepared and stored at tropical room temperature conditions (37$45^{\circ} \mathrm{C}$ and $95 \% \mathrm{RH}$ ) for 4 months. Chemical and sensory tests were performed for quality testing. The oxidative stability of ABF was performed by determining the conjugated dienes (CD), acid value (AV), free fatty acids (FFA) and peroxide value (PV) at regular intervals (2 weeks) under accelerated storage conditions $\left(63^{\circ} \mathrm{C}\right.$ for 6 weeks).

Results of the oxidative rancidity indicated that the addition of Covi 70 and $\mathrm{T} 25$ to the ABF significantly $(\mathrm{P}<0.05)$ retarded the oxidative rancidity as measured by the aforementioned parameters. No significant effects were detected in most of the tests between Covi 70 and T25 which emphasize the outstanding effect of Covi 70 in retarding the onset of rancidity and stabilizing the ABF under the experimental conditions.

Results of the chemical analysis indicated the presence of a significant $(\mathrm{P}<0.05)$ drop in both the moisture content and the $\mathrm{pH}$ values and a significant rise $(\mathrm{P}<0.05)$ in the TBA values of the stored cookies as a function of time. Both Covi 50 and Covi 70 exhibited a significant $(\mathrm{P}<0.05)$ effect in maintaining the aforementioned parameters as compared to the control and the synthetic antioxidant. The sensory evaluation results showed that higher scores for the taste, odour and overall acceptance were given to the Covi 70- containing cookies as compared to the control and the other added antioxidants.
\end{abstract}

Keywords : mixed tocopherols, synthetic antioxidants, anhydrous butter fat, oxidative rancidity, storage.

\section{INTRODUCTION}

Anhydrous butter fat (ABF) is produced at home and cottage levels in many Middle Eastern countries. A number of factors thus contribute to the keeping quality of $\mathrm{ABF}$, which include : the source and history of the butter before processing, the method of manufacture and the storage conditions (Singh et al., 1979, Basson, 1981, Hamzawi, 1990).

Oxidative changes of butter fat are one of the most important factors limiting the keeping quality of fat-rich dairy products and affects such products in numerous ways. Most noticeable are loss of flavour and aroma and subsequent development of rancidity (IFI, 1992, Shahidi, 1996).

It is often possible to add synthetic antioxidants to milk fat to improve its oxidative stability during storage. Both butylated hydroxyanisole (BHA) and butylated hydroxyt- oluene (BHT) are still the most widely used antioxidants. Their relatively low prices may restrain the use of naturally derived antioxidants (IFI, 1992, Loliger \& Wille, 1993). The use of natural antioxidants has received special attention because of the worldwide trend to avoid or reduce the use of synthetic food additives. These synthetic compounds have been considered potentially toxic if consumed routinely (Frankel, 1996, Auroma, 1998). The most important natural antioxidants are tocopherols, they are the most widely distributed and most extensively tested for food use (Buck \& Edwards, 1997, Neff et al., 2003).

Tocopherols claim about $50 \%$ of the Japanese market and 2\% of the US antioxidant market (IFI, 1992). Tocopherols are effective antioxidants in most food products deficient in natural antioxidants such as animal fat, waxes and butter fat (Giese, 1996, Berry, 2003). Alpha $(\alpha)$ tocopherol has considerable 
antioxidant properties but less than gamma $(\gamma)$ and delta $(\delta)$ tocopherols (Buck \& Edwards, 1997, Berry, 2004).

The antioxidative effects of tocopherols and ascorbyl palmitate (AP) were investigated in various fats and oils. Results showed that a distinct antioxidative action was obtained and remained stable in lard at tocopherol concentrations up to $2500 \mathrm{ppm}$ and decreased above this concentration. Increased stability of the fat was also observed due to high concentration of $\gamma$ - and $\delta$-isomers obtained from a natural soybean oil extract versus synthetic $\alpha$-tocopherol. The addition of ascorbyl palmitate to tocopherols produced an additional antioxidative effect in lard depending on tocopherol concentration (Timmerman \& Adams, 1989). Meanwhile, Hamzawi (1990) studied the combined antioxidative effect of phospholipids and $\alpha$-tocopherol on the stability of butter fat. Results indicated that the addition of phospholipids to butter fat increased the effectiveness of the antioxidant properties of $\alpha$-tocopherol. The effectiveness of some natural antioxidants (mixed tocopherols, extract of rosemary, ascorbic acid and ascorbyl palmitate) was compared against that of four major synthetic antioxidants (BHA, BHT, TBHQ and propyl gallate) in various fats and oils. Results showed that TBHQ was highly effective in lard and was more effective in combination with BHA. Tocopherols were also effective as the other used synthetic antioxidants and showed superior permanence and resistance to volatility compared with synthetic antioxidants in long term frying tests and during storage (IFI, 1992, Dougherty, 1993, Warner, 2003).

The objectives of this work were: (1) Study the storage stability of buffalo's ABF containing two concentrations of mixed tocopherols namely Covi-OxT50 and Covi-OxT70 versus a type of synthetic antioxidant (Tenox 25 ) as compared to a control during acceletrated storage conditions at $63^{\circ} \mathrm{C}$ for 6 weeks. (2) Chemical and sensory evaluation of a type of cookie product made from butter with the aforementioned added antioxidants concentrations together with a control sample were studied. Samples were stored at tropical conditions $\left(37-45^{\circ} \mathrm{C}\right.$ and $95 \%$ relative humidity typical to Jeddah City in Saudi Arabia) for four months.

\section{MATERIALS AND METHODS}

\section{Materials}

Butter samples: Five kilograms of buffalo's butter were purchased from vendors at a farm near Cairo. The butter sample was split into two subsamples. Half was kept as a butter while the other half was thermally heated in the traditional method without added salt to transform it to anhydrous butter fat, (ABF) ghee. Samples were stored frozen before mixing with the antioxidants at $-18^{\circ} \mathrm{C}$ for 2 weeks.

Antioxidants: Two types of natural tocopherols namely Covi-Ox T50 (Covi 50) and Covi-Ox T70 (Covi 70) were purchased from Henkel Corporation, IL, USA. Both are clear brownish red viscous oils containing mixed tocopherols concentrate. The following values (expressed as a percent of the total tocopherols are typical : $d-\alpha 14 \%, d-\beta 1 \%, d-\gamma 62 \%$ and d$\delta 23 \%$. Each gram of Covi 50 contains $500 \mathrm{mg}$ of total tocopherols, including a minimum of $400 \mathrm{mg}$ of non- $\alpha$-tocopherols. Each gram of Covi 70 contains $700 \mathrm{mg}$ of total tocopherols, including a minimum of $560 \mathrm{mg}$ of non- $\alpha$ tocopherols. Both types were applied at $0.02 \%$ of the total fat content (Doughrety, 1988). A synthetic type of antioxidants namely Tenox 25 (T25) was purchased from Eastman Chemical Company, TN, USA. It is a viscous golden brown oil containing 10\% butylated hydroxy toluene (BHT) and 10\% tertiary butyl hydroquinone (TBHQ) and 3\% citric acid. It was applied at $0.02 \%(200 \mathrm{ppm})$ based on fat weight according to FDA regulations.

\section{Methods}

Application of antioxidants: The antioxidants used in the present study were applied to the fat according to the direct method described by Eastman (1996) by heating the butter and/or unhydrous butter fat to $60^{\circ} \mathrm{C}$ $\left(140^{\circ} \mathrm{F}\right)$ and agitating sufficiently to dissolve the antioxidant. The gentle agitation was continued for an additional 20 min. to ensure uniform distribution.

Cookies preparation: The following ingredients were used in the formulation of cookies as $\mathrm{g} / 100 \mathrm{~g}$ of the total ingredients: butter $29 \%$, icing sugar $10.1 \%$, flour $50.7 \%$, eggs $7.6 \%$, salt $0.3 \%$, baking powder $0.3 \%$ and vanilla $0.1 \%$. Cookies were prepared as described by Smith (1972). Cookie's product with the added concentrations of antioxidants 
as mentioned previously were put in plastic plates and wrapped with polyethylene cover, stored for 4 months at room temperature which ranged between $37-45^{\circ} \mathrm{C}$, typical to Jeddah City in Saudi Arabia, and evaluated monthly for chemical and sensory tests.

Determination of oxidative rancidity in the anhydrous butter fat (ABF): The $\mathrm{ABF}$ treated with the added levels of tocopherols, synthetic antioxidant and the control sample were subjected to an accelerated aging test where samples were stored separately in clear capped glass jars, put in a forced draft oven adjusted at a constant temperature of $63^{\circ} \mathrm{C}$ for 6 weeks. Samples were withdrawn at 2 weeks interval for chemical evaluation. Oxidative rancidity was evaluated by the measurement of conjugated dienes (CD) as described by IUPAC (1978). Absorbance was measured at wave length of $234 \mathrm{~nm}$ using a spectrophotometer (Ultraspec, 2000, Pharmacia Biotech, USA). The hydrolytic rancidity was evaluated by determining both the acid value (AV) and the free fatty acid (FFA) content of the ABF following the IUPAC (1979), results were expressed as g oleic acid $\mathrm{Kg}^{-1}$. The peroxide value (PV) was determined according to AOCS official methods (1986) by titration with standard sodium thiosulphate solution and calculated as $\mathrm{mEq} / \mathrm{O}_{2} \mathrm{~kg}$ sample.

Quality tests of cookies made from butter: The moisture content of the cookies was monitored monthly using an electric oven at $105 \pm 0.5^{\circ} \mathrm{C}$ for $2-3$ hrs until constant weight (AOAC, 1984). The $\mathrm{pH}$ was performed in $10 \mathrm{~g}$ sample thoroughly mixed with $90 \mathrm{ml}$ distilled water and the $\mathrm{pH}$ measured by an ATC pH meter G353, UK. The oxidative rancidity of the stored cookies was evaluated by the thiobarbituric acid number (TBA) as described by Tarladgis et al. (1960). The TBA number was calculated as mg malonaldehyde/kg sample.

Sensory evaluation: The cookies were evaluated for sensory attributes every one month interval for 4 months by means of ten panelists from the Department of Food and Nutrition (King Abdulaziz University, Jeddah, KSA), where an evaluation sheet was distributed for the ranking test. The attributes tested were colour, odour, taste, texture and overall acceptance. Scores were distributed on a five point scale ranging between 1 and 5 where 5 stands for maximum acceptance and
1 for maximum rejection due to negative distinct changes in one or more of the tested attributes. Tap water and salt crackers were introduced between each treatment (Moskwitz, 1985).

\section{Statistical analysis :}

The general linear model procedure (GLA) was used to perform analysis of variance (ANOVA) between time $\times$ treatment using the Statistical Analysis System (SAS, 1985). Duncan's Multiple Range Test was performed to determine differences among means.

\section{RESULTS AND DISCUSSION}

Results presented in Table (1) showed the presence of a significant $(\mathrm{P}<0.05)$ increase in the values of the conjugated dienes (CD) of the ABF stored at accelerated temperature conditions as a function of time which was significantly obvious at the fourth week of storage. The application of both natural and synthetic antioxidants significantly $(\mathrm{P}<0.05)$ decreased the $\mathrm{CD}$ values as compared to the control. As a matter of fact, Covi 50 successfully achieved the lowest value in this respect as compared to the control and was not significantly different from the other antioxidants used in the present study. It was well documented that the CD increase is proportional to the uptake of oxygen and the formation of peroxides in the early stages of oxidation (Gray, 1978).

It was also clear from Table (1) that both the acid value and the FFA values showed a significant increase $(\mathrm{P}<0.05)$ as a function of time. Both Covi 70 and T 25 had a significant effect in reducing hydrolysis as compared to the control and Covi 50, but were not significantly different from each other emphasizing the role of the natural antioxidant Covi 70 in this respect. These results are in accordance to Thakar et al. (1984), Iskandar et al. (1985) and Warner (2003) who reported the effect of some natural plant antioxidants in controlling hydrolytic rancidity in cow's ABF during storage.

Data in Table (1) also show the peroxide values of $\mathrm{ABF}$ during the accelerated storage conditions. Results showed a significant gradual rise in PV's with time reaching its maximum $\left(18.82 \mathrm{mEqO}_{2} / \mathrm{kg}\right)$ at the end of the storage period. The addition of both natural and synthetic antioxidants greatly restricted the development 
Table 2: Chemical evaluation of butter cookies with different added levels of natural and synthetic antioxidants stored at tropical conditions for $\mathbf{4}$ months

\begin{tabular}{|c|c|c|c|c|c|c|}
\hline \multirow{2}{*}{$\begin{array}{l}\text { Tested pa- } \\
\text { rameters }\end{array}$} & \multirow{2}{*}{$\begin{array}{c}\text { Storage } \\
\text { time } \\
\text { (months) }\end{array}$} & \multicolumn{4}{|c|}{ Treatments } & \multirow{2}{*}{$\begin{array}{c}\text { Mean } \overline{(x} \\
\text { time }\end{array}$} \\
\hline & & Control & Covi 50 & Covi 70 & T25 & \\
\hline \multirow{6}{*}{ Moisture } & 0 & 7.51 & 8.08 & 10.44 & 9.62 & $8.91^{\mathrm{a}}$ \\
\hline & 1 & 7.08 & 8.05 & 8.06 & 9.42 & $8.15^{\mathrm{b}}$ \\
\hline & 2 & 7.05 & 7.85 & 7.93 & 8.35 & $7.80^{\mathrm{b}}$ \\
\hline & 3 & 7.00 & 6.63 & 6.59 & 6.24 & $6.61^{\mathrm{c}}$ \\
\hline & 4 & 6.13 & 5.75 & 6.40 & 5.94 & $6.05^{c}$ \\
\hline & $\overline{\mathrm{x}}$ treatment & $6.95^{\mathrm{a}}$ & $7.27^{\mathrm{b}}$ & $7.88^{\mathrm{c}}$ & $7.91^{\mathrm{c}}$ & \\
\hline \multirow{6}{*}{$\mathrm{pH}$} & 0 & 5.48 & 5.53 & 5.50 & 5.54 & $5.51^{\mathrm{a}}$ \\
\hline & 1 & 4.73 & 4.94 & 5.38 & 5.20 & $5.06^{\mathrm{b}}$ \\
\hline & 2 & 6.98 & 4.35 & 5.26 & 4.85 & $4.61^{\mathrm{C}}$ \\
\hline & 3 & 3.23 & 3.76 & 5.14 & 4.51 & $4.16^{\mathrm{d}}$ \\
\hline & 4 & 2.48 & 3.70 & 5.02 & 4.16 & $3.84^{\mathrm{e}}$ \\
\hline & $\overline{\mathrm{x}}$ treatment & $3.98^{\mathrm{a}}$ & $4.45^{\mathrm{b}}$ & $5.26^{\mathrm{c}}$ & $4.58^{\mathrm{d}}$ & \\
\hline \multirow{6}{*}{ TBA* } & 0 & 0.179 & 0.125 & 0.191 & 0.177 & $0.168^{\mathrm{a}}$ \\
\hline & 1 & 0.424 & 0.183 & 0.216 & 0.250 & $0.268^{\mathrm{b}}$ \\
\hline & 2 & 0.448 & 0.327 & 0.267 & 0.280 & $0.330^{c}$ \\
\hline & 3 & 0.541 & 0.242 & 0.300 & 0.325 & $0.356^{\mathrm{d}}$ \\
\hline & 4 & 0.750 & 0.247 & 0.325 & 0.585 & $0.476^{\mathrm{e}}$ \\
\hline & $\overline{\mathrm{x}}$ treatment & $0.468^{\mathrm{a}}$ & $0.225^{\mathrm{b}}$ & $0.259^{c}$ & $0.327^{\mathrm{d}}$ & \\
\hline
\end{tabular}

* TBA : Thiobarbituric acid expressed as mg malonaldehyde / kg sample.

Means in a column not sharing the same superscript are significantly different at $\mathrm{P}<0.05$.

of cookies as a function of time. The $\mathrm{pH}$ value of the cookies at the beginning of the experiment was 5.51 then dropped to 3.84 at the end of the storage period indicating the progression of hydrolysis which is more liable in low moisture products (Allen \& Hamilton, 1989). The application of the added antioxidants significantly $(\mathrm{P}<0.05)$ protected the drop in the $\mathrm{pH}$ of cookies where the natural antioxidant Covi 70 was more pronounced in this respect as compared to the control and the other antioxidants used in the present study.

The TBA number of the stored cookies (Table 2) exhibited a significant rise $(\mathrm{P}<0.05)$ with the elapse of time. The application of both natural and synthetic antioxidants greatly minimized the increase in TBA number where Covi 50 was the most effective in this respect as compared to the control and the synthetic antioxidant ( $\mathrm{T}$ 25). It is worth mentioning that high temperature, temperature fluctuations and high relative humidity cause the movement and migration of fats causing rancidity problems (Manley, 1996). It was also emphasized by Acker (1962) and Amr (1991) that the low water content of some products may initiate the free-radical activation.

As it can be seen from Table (3), the addition of different concentrations of natural and synthetic antioxidants significantly $(\mathrm{P}<0.05)$ enhanced the odour and taste attributes of the stored cookies as they were highly accepted by the panelists up to the end of the storage time as compared to the control samples. As a matter of fact, cookies containing Covi 70 were highly scored for odour, taste and the overall acceptance as compared to the control and the other added antioxidants. The addition of the different antioxidants had no significant effects on the colour and texture of the cookies. It was confirmed by Hamzawi (1990) and Amr (1991) that oxidation affects negatively the quality of food products in several manner, the most distinct of all is the loss of flavour and appearance of rancidity. These facts also attributed to the nature of 
Table 3: Effect of different added levels of natural and synthetic antioxidants on the sensory attributes of butter cookies stored at tropical conditions for $\mathbf{4}$ months

\begin{tabular}{|c|c|c|c|c|c|c|}
\hline \multirow{2}{*}{$\begin{array}{l}\text { Sensory at- } \\
\text { tribute }\end{array}$} & \multirow{2}{*}{$\begin{array}{l}\text { Storage } \\
\text { time } \\
\text { (months) }\end{array}$} & \multicolumn{4}{|c|}{ Treatments } & \multirow{2}{*}{$\begin{array}{c}\text { Mean } \overline{(x)} \\
\text { time }\end{array}$} \\
\hline & & Control & Covi 50 & Covi 70 & T25 & \\
\hline \multirow{6}{*}{ Colour } & 0 & 4.30 & 3.75 & 4.30 & 4.30 & $4.16^{\mathrm{a}}$ \\
\hline & 1 & 4.40 & 4.80 & 4.50 & 4.20 & $4.47^{\mathrm{a}}$ \\
\hline & 2 & 3.90 & 3.70 & 3.40 & 4.20 & $3.80^{\mathrm{a}}$ \\
\hline & 3 & 3.90 & 3.40 & 3.50 & 3.40 & $3.55^{\mathrm{a}}$ \\
\hline & 4 & 3.30 & 3.60 & 4.30 & 3.50 & $4.42^{\mathrm{a}}$ \\
\hline & $\overline{\mathrm{x}}$ treatment & $3.96^{\mathrm{a}}$ & $3.85^{\mathrm{a}}$ & $4.00^{\mathrm{a}}$ & $4.52^{\mathrm{a}}$ & \\
\hline \multirow{6}{*}{ Odour } & 0 & 3.00 & 3.70 & 3.90 & 4.10 & $3.67^{\mathrm{a}}$ \\
\hline & 1 & 3.20 & 4.10 & 4.10 & 3.80 & $3.80^{\mathrm{a}}$ \\
\hline & 2 & 3.70 & 3.90 & 3.70 & 3.70 & $3.75^{\mathrm{a}}$ \\
\hline & 3 & 1.80 & 2.85 & 3.10 & 2.80 & $2.63^{\mathrm{b}}$ \\
\hline & 4 & 1.95 & 3.20 & 3.60 & 3.40 & $3.03^{\mathrm{b}}$ \\
\hline & $\overline{\mathrm{x}}$ treatment & $2.73^{\mathrm{a}}$ & $3.55^{\mathrm{b}}$ & $3.68^{\mathrm{b}}$ & $3.56^{\mathrm{b}}$ & \\
\hline \multirow{6}{*}{ Taste } & 0 & 3.40 & 3.70 & 4.10 & 4.50 & $3.92^{\mathrm{a}}$ \\
\hline & 1 & 3.50 & 4.20 & 4.10 & 3.80 & $3.90^{\mathrm{a}}$ \\
\hline & 2 & 3.20 & 4.00 & 3.50 & 3.60 & $3.57^{\mathrm{a}}$ \\
\hline & 3 & 2.00 & 3.20 & 3.00 & 2.90 & $2.77^{\mathrm{b}}$ \\
\hline & 4 & 1.95 & 1.95 & 3.60 & 2.90 & $2.60^{\mathrm{b}}$ \\
\hline & $\overline{\mathrm{x}}$ treatment & $2.81^{\mathrm{a}}$ & $3.41^{\mathrm{b}}$ & $3.66^{\mathrm{b}}$ & $3.54^{\mathrm{b}}$ & \\
\hline \multirow{6}{*}{ Texture } & 0 & 4.10 & 4.00 & 4.20 & 4.30 & $4.15^{\mathrm{a}}$ \\
\hline & 1 & 4.00 & 3.70 & 4.10 & 3.80 & $3.90^{\mathrm{ab}}$ \\
\hline & 2 & 3.70 & 4.20 & 4.0 & 4.10 & $4.00^{\mathrm{a}}$ \\
\hline & 3 & 3.30 & 3.80 & 3.60 & 3.30 & $3.50^{\mathrm{b}}$ \\
\hline & 4 & 3.50 & 3.50 & 4.20 & 3.70 & $3.72^{\mathrm{ab}}$ \\
\hline & $\overline{\mathrm{x}}$ treatment & $3.72^{\mathrm{a}}$ & $3.84^{\mathrm{a}}$ & $4.02^{\mathrm{a}}$ & $3.84^{\mathrm{a}}$ & \\
\hline \multirow{6}{*}{$\begin{array}{l}\text { Overall accep- } \\
\text { tance }\end{array}$} & 0 & 3.50 & 3.90 & 4.10 & 4.30 & $3.95^{\mathrm{a}}$ \\
\hline & 1 & 3.20 & 4.00 & 4.05 & 3.80 & $3.76^{\mathrm{a}}$ \\
\hline & 2 & 3.10 & 3.90 & 3.60 & 4.00 & $3.65^{\mathrm{a}}$ \\
\hline & 3 & 1.60 & 3.30 & 3.10 & 2.80 & $2.70^{\mathrm{b}}$ \\
\hline & 4 & 2.00 & 3.00 & 3.70 & 2.90 & $2.90^{\mathrm{b}}$ \\
\hline & $\overline{\mathrm{x}}$ treatment & $2.68^{\mathrm{a}}$ & $3.62^{\mathrm{b}}$ & $3.71^{\mathrm{b}}$ & $3.56^{\mathrm{b}}$ & \\
\hline
\end{tabular}

Means in a column not sharing the same superscript are significantly different at $\mathrm{P}<0.05$.

fatty acids comprised in the milk butter where butyric acid is the most abundant together with those fatty acids of low molecular weight and in less manner those unsaturated ones. Such a variety of fatty acids is liable to hydrolysis and autoxidation under fluctuated storage conditions causing the appearance of unacceptable flavours usually described as cheesy-off flavour. Thus, the aforementioned results of the sensory evaluation showed that the application of all types of antioxidants greatly prevented the appearance of off-flavours where the nat- ural antioxidant Covi 70 showed a pronounced role in this respect.

It may be concluded that the highly concentrated natural antioxidant Covi 70 was more pronounced in stabilizing the fat material experimented under the accelerated high temperature conditions and in the cookies stored at room temperature at tropical conditions. Covi 70 was equally effective in most of the cases as the powerful synthetic antioxidant Tenox 25 emphasizing the capability of Covi 70 in stabilizing the onset of rancidity in both $\mathrm{ABF}$ and butter-cookies. 


\section{REFERENCES}

Acker, L. 1962. Enzymic reactions in foods at low moisture content. Advances in Food Res. 11: 263-330.

Allen, J.C. \& Hamilton, R.J. 1989. Natural Antioxidants, In : Rancidity in Foods. Hamilton, R.J. (ed.). John Wily \& Sons, N.Y. 2: 105123.

Almasi, E. 1979. Dependence of the amount of bound water of foods on temperature. ACTA Aliment. 8 (1): 41-56.

Amr, A.S. 1991. Effectiveness of synthetic and potential natural antioxidants in improving the stability of sheep's anhydrous butter fat during long-term storage. J. Sci. Food Agric. 55: 75-85.

AOAC 1984. Official Methods of Analysis, $14^{\text {th }}$ ed. Association of Official Analytical Chemists. Washington, DC.

AOCS 1986. Official and Recommended Practices of the American Oil Chemists' Society, $14^{\text {th }}$ Edition. Edited by Walker, R., Champaign.

Auroma, O.I. 1998. Free radicals, oxidative stress and antioxidants in human health and disease, J. Am. Oil Chem. Soc., 75: 199-212.

Basson, P. 1981. Women and traditional food technologies. Changes in rural Jordan. Ecol Food Nutr. 11(1): 17-23.

Berry, D. 2003. Fats' chance. Food Product Design: Applications, June, p. 1-7.

Berry, D. 2004. Keeping Foods Fresh. Food Product Design: Design Elements, January, p. 1-9.

Buck, D.F. \& Edward, M.K. 1997. Antioxidants to prolong shelf-life. Food Tech. Intern. p. 29-33.

Dougherty, M.E. 1988. Tocopherols as food antioxidants. Cereal Foods World, 33:222-232.

Dougherty, M.E. 1993. Effectivness of natural antioxidants compared to synthetic antioxidants. International Food Ingredient (IFI) NR. 3.

Eastman 1993. Tenox food grade antioxidants. Publication No. 26-109k, Eastman Chemical Co., King Sport, Tenn. USA.

Eastman 1996. Tenox food grade antioxidants. Eastman Publication No. Zg-262C. Eastman Chemical Company, Kingsport, TN 37668-5280 USA.

Frankel, E.N. 1996. Antioxidants in lipid foods and their impact on food quality. Food Chem. 57: 51-55.

Giese, J. 1996. Antioxidants : Tools of preventing lipid oxidation. Food Technol. 50(11): 7380.

Gray, J.I. 1978. Measurement of lipid oxidation. J. Am. Oil. Chem. Soc. 55: 539-546.

Hamzawi, L.F. 1990. Role of phospholipids and alpha tocopherol as natural antioxidants in buffalo butter fat. Milchwissen Schaft 45 (2) : 95-97.

International Food Ingredients (IFI) 1992. Focus on Antioxidants. IFI, NR. 6, p. 39-45.
International Union of Pure and Applied Chemistry (IUPAC) 1978. Standard Methods for the Analysis of Oils and Fats and Derivatives. $7^{\text {th }}$ ed., Blackwell Sci. Pub. Ltd., Polo, Alto, C.A.

International Union of Pure and Applied Chemistry (IUPAC) 1979. Standard Methods for the Analysis of Oils, Fats and Derivatives Method 2. 504, $6^{\text {th }}$ ed. Pergamon Press, Oxford, England.

Iskandar, M., Bayomi, J. \& Shalabi, S. 1985. Composition and storage stability of commercial anhydrous milk fat and hydrogenated oils. J. Food Technol. 20(1): 83-88.

Loliger, J. 1991. Natural antioxidants. Lipid Technology. 4: 58-61.

Loliger, J. \& Wille, H.J. 1993. Natural antioxidants, Oils and Fats International 9: 8-22.

Manley, D. 1996. Technology of Biscuits, Crackers and Cookies. Woodhead Publishing Limited, Abington Hall, Abington, Cambridge, England, p. 459-465.

Moskwitz, H.R. 1985. New Directions for Product Testing and Sensory Analysis of Foods, p. 75, Food Nutrition Press, Trumbull, Connecticut.

Neff, W.E., Byrdwell, W.C., Warner, K.A. \& Eller, F.J. 2003. Effect of gamma tocopherol on the formation of nonvolatile lipid degradation products during the frying of potato chips in triolein. J. Am. Oil. Chem. Soc. 80: 620-625.

SAS 1985. Statistical Analysis System, (5 ${ }^{\text {th }}$ ed) Statistical Analysis System Institute, Cary, NC.

Shahidi, F. 1996. Natural Antioxidants: Chemistry, Health Effects and Applications. AOCS Press, Champaign, Illinois, USA.

Singh, S., Ram, B. \& Mittal, S. 1979. Effect of phospholipids and methods of manufacture on flavour and keeping quality of ghee. Indian J. Dairy Sci. 32(2): 161-167.

Smith , W.H. 1972. Biscuits, Crakers and Cookies, In : Formulas, Magazines for Industry, Vol. 2, p. 136, New York.

Tarladgis, B.G., Watts, B.M., Younathan, M.T. \& Dugan, L. 1960. A distillation method for the quantitative determination of malonaldehyde in rancid food. J. Am. Oil. Chem. Soc. 37: 44-48.

Timmerman, F. \& Adams, W.F. 1989. Antioxidative effect of tocopherols and ascorbyl palmitate. European Food and Drink Review 48: 51-52.

Thakar, P., Prajapate, P., Pandya, A., Updadhya, K. \& Vyas, S. 1984. Effect of some natural antioxidants on free fatty acid and peroxide value of ghee during storage. Gujarat Agri. Univ. Res. J. 9(2): 40-47.

Warner, K.A. 2003. Effects of Antioxidants in Frying Oils. In: Gupa, M., Warner, K, White, P. (eds). Chemistry of Frying Oils, AOCS Press, Cham Paign, IL, p. 210-227. 


\section{التوكوفيرولات: دورها في ثبات الزبلد منزوع الماء (السهن) وأقراص الكمك المك المصنعة من الزبلد (كوكيز)

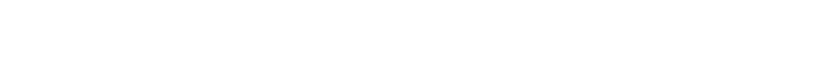

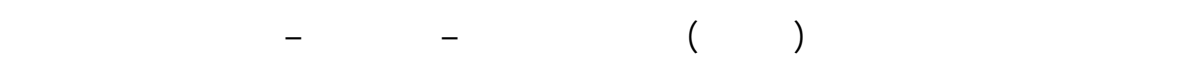

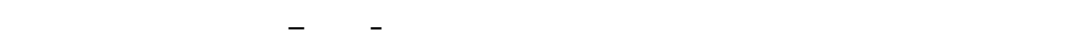

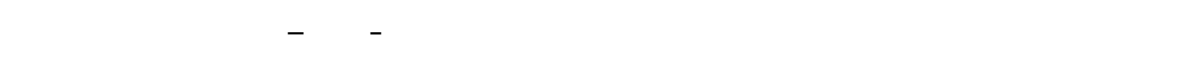

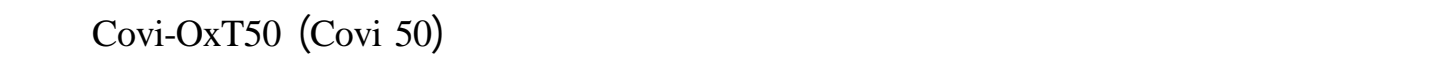

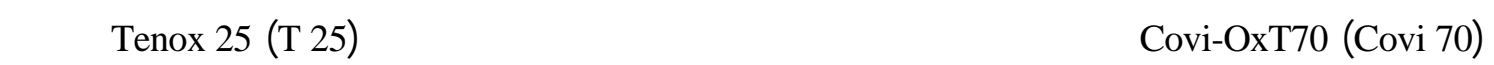

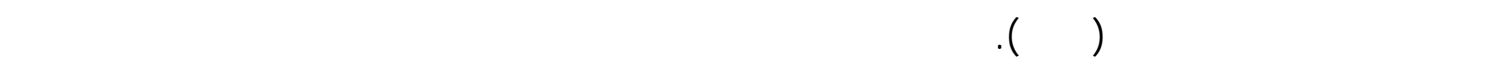

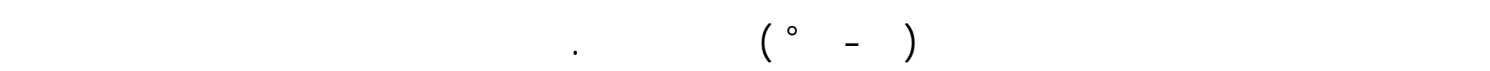
لقييم جودة المنتج تمت الظروف الساقة.

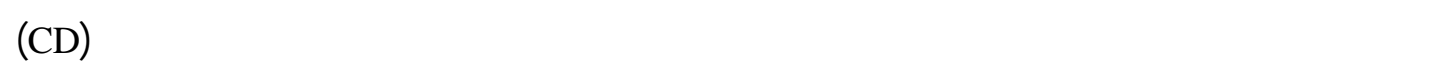

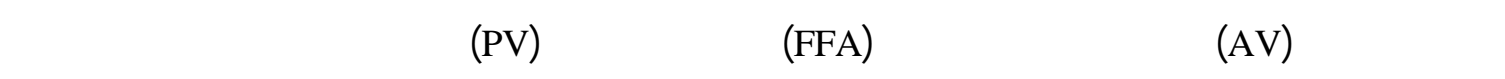
تحتظروف تجريبية معجلة من درجة الحرارة (سجمْ المدة 7 أسلبيع).

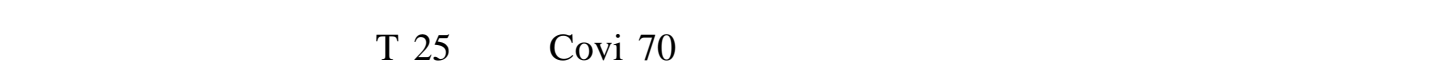

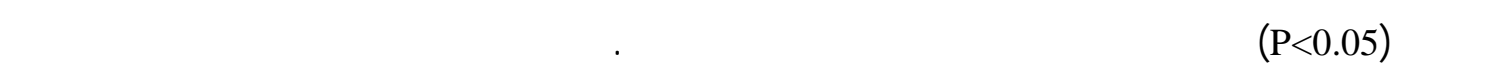

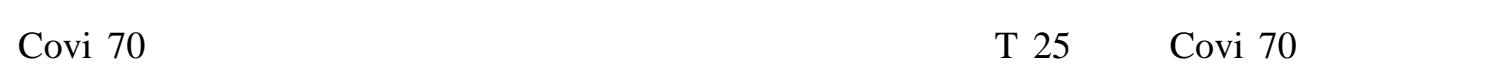

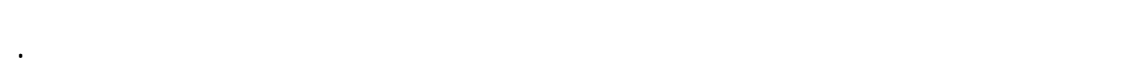

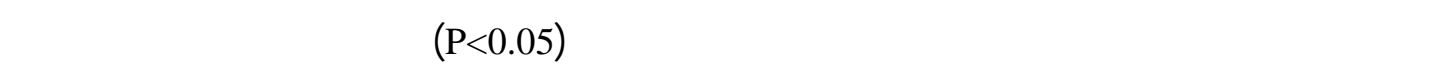

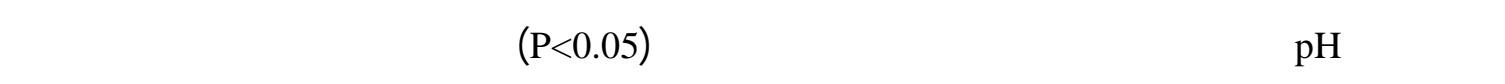

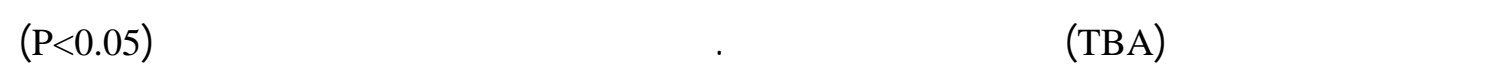

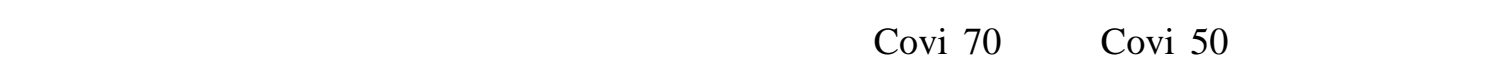

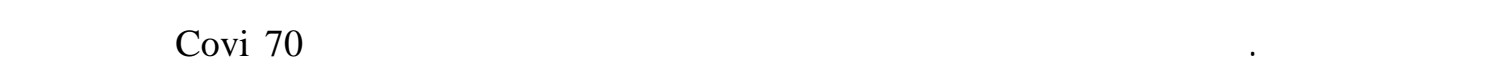

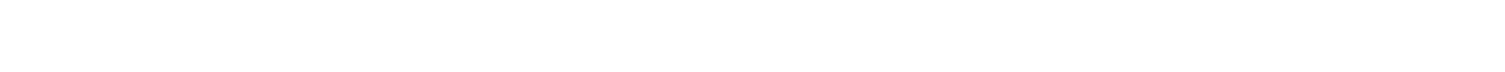
المستخمة في الدرلسة. 